\title{
COVID-19 pandemic conditions: the role of sustainable environment in intentions to give zakat, infaq, and sadaqah
}

\author{
Alin Fithor ${ }^{*}$, Dewi Muliana ${ }^{2}$ Teuku Afrizal ${ }^{3}$, and Jumadil Saputra ${ }^{4}$ \\ ${ }^{1}$ Diponegoro University, 50275 Semarang, Indonesia \\ ${ }^{2}$ Pancasakti University, 52121 Tegal, Indonesia \\ ${ }^{3}$ National University of Malaysia, 43600, Bangi, Selangor, Malaysia \\ ${ }^{4}$ University of Malaysia, Terengganu, 21300 Kuala Terengganu, Terengganu, Malaysia
}

\begin{abstract}
The purpose of this paper is to determine the factors that influence the intention to give zakat, infaq, and sadaqah of Indonesian Muslim communities using the Theory of Planned Behavior (TPB) model. The sample data used in this study were 128 respondents and processed with SPSS to test the significance of the regression model. The independent variables used are religious beliefs, attitudes, subjective norms, and perceived behavioral control, while the intention is the dependent variable. The results showed that the idea of a sustainable environment had a positive and significant effect on attitudes. In addition, attitudes, subjective norms, and perceived behavioral control also have a positive and significant impact on intentions to the surrounding community. Amil institutions can predict the behavior of muzak through this paper. As for academics, this paper is used for further research by integrating perceived behavioral control as a predictor of Indonesian Muslim intentions. This study is an initial study that investigates the determinants of muzak behavior through the TPB model. Therefore, this paper will be helpful to a contribution from academics regarding the behavior Muslim community in the conditions COVID-19 pandemic in Indonesia and the world.
\end{abstract}

\section{Introduction}

The pandemic continues to provide bad news for countries in the world, including Indonesia. Indonesia's COVID-19 case fatality rate (CFR) reached $2.7 \%$ on Monday (June 21, 2021). COVID-19 has claimed 54,956 lives. Indonesia's CFR percentage is higher than the global 2.2\% [1]. The increasing trend of deaths, but more than that, the COVID-19 outbreak has also impacted the economy of Indonesian millennial families. Millennial families do not have the savings to survive this pandemic. Most of them are also in debt. They also began to complain about their family's economic condition, so they were not satisfied with their family's economic [2].

The Indonesian Survey Institute (LSI) released a survey related to Indonesia's economic condition during a pandemic on July 18, 2021. As a result, most respondents rated the current national economy as bad; as many as $44.9 \%$ of respondents said the Indonesian economy was bad. People feel that their lives have become worse due to COVID-19. The majority, $70.9 \%$ of them, feel very/quite likely that their lives will worsen due to the economic impact of the COVID-19 outbreak. Public pressure for the government to prioritize economic problems is $50.7 \%$ compared to prioritizing health problems (46.2\%). People also think that the blockades carried out by the government should be stopped. The majority of the people, 57.1\%, feel that the PSBB is sufficient and can be stopped so that the economy can start immediately. However, 38.8\% thought that PSBB should be continued so that the spread of the COVID-19 virus could be contained [3].

COVID-19 has had a huge domino effect on human life globally. The health crisis that initially occurred eventually created other crises, such as economic and social crises. One of the efforts to reduce poverty and economic inequality is to maximize zakat collection during the current COVID-19 pandemic. The potential for zakat, infaq, and sadaqah (ZIS) is reliable. The study of the Zakat Potential Mapping Index (IPPZ) conducted by the BAZNAS Puskas noted that in 2018 the potential for zakat in Indonesia reached 233 trillion rupiahs [4].

This great potential turned out to have obstacles, and in fact, there was a significant decrease in zakat during the pandemic was due to 48.4 percent of BAZNAS muzak experiencing a decrease in income (Sari et al., 2020). This condition will certainly affect the assets that can be muzak, especially from income zakat, which has a zakat base based on income or regular income from work that does not violate sharia. Not only that, the large potential for zakat, infaq, and sadaqah (ZIS) has not been well organized during the pandemic. The COVID-19 condition has made Zakat Management Organizations (OPZ) have difficulty collecting zakat conservatively by opening outlets in crowds and shopping centers [4]. The collection channels that previously could be utilized cannot be used optimally due to the Large-Scale Social Restriction policy

\footnotetext{
* Corresponding author: afithor@gmail.com
} 
or the COVID-19 health protocol. These two things can have a negative influence on people's behavior in issuing ZIS in Indonesia.

The behavioral approach has been described by Ajzen 1991 through the theory of planned behavior (TPB). TPB is a development of the theory of rational action (TRA). TRA is a theory that is only intended for behaviors easily carried out by individuals without causing obstacles to do so [5]. Because the individual determines behavior, but there is a controlling factor in performing a behavior, the perceived behavioral control variable is added [5] TPB is a theory that aims to direct behavior into real action. TPB can reveal the reality of determining the variables that affect behavior [5].

Research on zakat, infaq, and sadaqah (ZIS) during a pandemic is very important, but there are very few references. In previous research, several factors influenced the intention of someone who issued his ZIS, such as religious beliefs, attitudes, subjective norms, and perceived behavioral control [6]. However, other studies have shown different things, such as [7], proving that subjective norms cannot form zakat intentions. Likewise, [8] research proves that perceived behavioral control cannot form a Muslim's intention to tithe.

\section{Material and Methods}

This research is included in the field research using a quantitative approach. The data in this study were taken using a survey method. The survey was conducted using a questionnaire as a data collection technique, and it aims to take a sample from the population [9]. This study collects information from a population of entities, aiming to compile a quantitative description of the attributes possessed by a larger population of which the entity is also a part [10]

A purposive sampling technique was used in the sampling process. Purposive sampling is a sampling technique carried out using certain criteria [11].

\subsection{The Theory of Religious Beliefs}

Religious beliefs affect attitudes [12], so the first hypothesis can be built:

H10: There is no effect of religious beliefs on attitudes.

H1a: There is an influence on religious beliefs on attitudes.

\subsection{Attitude Theory}

Attitudes affect the intention to tithe [12], so the first hypothesis can be built:

H10: There is no effect on attitudes towards the intention to give ZIS.

H1a: There is an effect on attitudes towards the intention to give ZIS.

\subsection{Subjective Norm Theory}

Subjective norms affect the intention to tithe [12], so the first hypothesis can be built:

H20: There is no effect on subjective norms on the intention to give ZIS.

H2a: There is an effect on subjective norms on the intention to give ZIS.

\subsection{Perceived Behavioral Control Theory}

Perceived behavioral control affects the intention to tithe [12], so the first hypothesis can be built:

H30: There is no effect on perceived behavioral control on the intention to give ZIS.

$\mathrm{H} 3 \mathrm{a}$ : There is an effect on perceived behavioral control on the intention to give ZIS.

The research instrument used in this study was a questionnaire distributed online. The measurement scale used in this research instrument is a Likert scale with a range of 1 to 5 . Value $1=$ strongly disagree, number $2=$ disagree, number $3=$ neutral, number $4=$ agree, and number 5 = strongly agree. Demographically, respondents are shown in Table 1.

\section{Result and Discussion}

Table 1 shows the demographic recapitulation of the respondents taken in this study. The table shows that the gender of the respondents who participated in this study $52.3 \%$ was male, and the remaining $47.7 \%$ were female. Respondents are also in productive age; it is proven that most respondents are aged between $17-40$, namely $88.3 \%$, the rest are spread in the age range between 41-50 years. Most of the respondents came from Central Java, namely $66.4 \%$, the remaining $33.6 \%$ were spread in the provinces of Aceh, Banten, DIY, DKI Jakarta, West Java, East Java, Jambi, West Kalimantan, NTB, NTT, South Sulawesi, and West Sumatra.

The respondents' background is quite heterogeneous, as seen from the distribution of high school graduates as much as $38.3 \%$, undergraduate $35.2 \%$, master's degree $24.2 \%$, and diploma $2.3 \%$. When viewed from the background of the respondents' work, most work in the field of education, which is as much as $75 \%$, the remaining $25 \%$ work in other fields. The income of $62.5 \%$ of respondents is less than 2 million, $28.9 \%$ is $2-5$ million, $5.5 \%$ is $6-10$ million, and $3.1 \%$ is more than 10 million per month

From the KMO and Bartlett test of sphericity, it can be seen that the KMO value is 0.834 , which means the value is making better. While the Bartlett of Spherecity value is 0.000 , which means the test results are significant. From the validity test, it can also be seen that the research instrument is valid.

Table 3 shows the value of the instrument reliability test by showing the calculation of the Cronbach alpha value. From these calculations, it can be seen that the Cronbach alpha value for the religious belief variable is 0.870 , the attitude is 0.745 , the subjective norm variable is 0.798 , the perceived behavioral control variable is 
0.844 , and the intention variable is 0.870 . From the Cronbach alpha value that exceeds 0.6 , it can be concluded that the research instrument is reliable. In addition, all indicators used in this study are valid; it is proven that the Pearson correlation value of each indicator is greater than the $r$ table value of 0.146 .

Table 1. Information on Demographic

\begin{tabular}{|c|c|}
\hline Demographic & Percentage \\
\hline \multicolumn{2}{|l|}{ Gender } \\
\hline Male & 52.3 \\
\hline Female & 47.7 \\
\hline \multicolumn{2}{|l|}{ Age } \\
\hline $17-20$ & 38.3 \\
\hline $21-25$ & 12.5 \\
\hline $26-30$ & 11.7 \\
\hline $31-35$ & 15.6 \\
\hline $36-40$ & 10.2 \\
\hline $41-45$ & 7.0 \\
\hline $46-50$ & 2.3 \\
\hline Over 50 year & 2.3 \\
\hline \multicolumn{2}{|l|}{ Province } \\
\hline Aceh & 1.6 \\
\hline Banten & 1.6 \\
\hline Yogyakarta & 1.6 \\
\hline Jakarta & 7.8 \\
\hline West Java & 7.0 \\
\hline Jambi & 1.6 \\
\hline Central Java & 66.4 \\
\hline East Java & 6.2 \\
\hline West Kalimantan & 2.3 \\
\hline West Nusa Tenggara & 0.8 \\
\hline East Nusa Tenggara & 0.8 \\
\hline South Sulawesi & 1.6 \\
\hline West Sumatera & 0.8 \\
\hline \multicolumn{2}{|l|}{ Education } \\
\hline Senior High School & 38.3 \\
\hline Diploma & 2.3 \\
\hline Bachelor & 35.2 \\
\hline Master & 24.2 \\
\hline \multicolumn{2}{|l|}{ Profession } \\
\hline Financial Services Sector & 1.6 \\
\hline Personal Services & 1.6 \\
\hline Tourism Services Sector & 2.3 \\
\hline General Services Sector & 5.5 \\
\hline Health Sector & 0.8 \\
\hline Construction Area & 1.6 \\
\hline Manufacturing Field & 0.8 \\
\hline Government Sector & 2.3 \\
\hline Education & 75.0 \\
\hline Trade Area & 4.7 \\
\hline Telecommunications Field & 0.8 \\
\hline Others & 3.2 \\
\hline \multicolumn{2}{|l|}{ Income } \\
\hline Less than 2 million & 62.5 \\
\hline $2-5$ million & 28.9 \\
\hline 6-10 million & 5.5 \\
\hline More than 10 million & 3.1 \\
\hline
\end{tabular}

Table 2. The Result of KMO and Bartlett of Sphericity

\begin{tabular}{|l|l|}
\hline Testing & Value \\
\hline Sample Adequacy KMO & 0.834 \\
\hline Bartlett of Sphericity & $0.000^{*}$ \\
\hline
\end{tabular}

*significant at $\alpha<0.05$

Table 3. Convergent Validity and Reliability Test

\begin{tabular}{|c|c|}
\hline Item & P-Correlation \\
\hline \multicolumn{2}{|l|}{ Religious Beliefs $(C R=0.870) * *$} \\
\hline KA1 & $0.486^{*}$ \\
\hline KA2 & $0.690^{*}$ \\
\hline KA3 & $0.883^{*}$ \\
\hline \multicolumn{2}{|l|}{ Attitude $(\mathrm{CR}=0.745)^{* *}$} \\
\hline SK1 & $0.676^{*}$ \\
\hline SK2 & $0.899 *$ \\
\hline SK3 & $0.856^{*}$ \\
\hline \multicolumn{2}{|l|}{ Subjective Norm $(\mathrm{CR}=0.798)^{* *}$} \\
\hline NS1 & $0.712 *$ \\
\hline NS2 & $0.860^{*}$ \\
\hline NS3 & $0.875^{*}$ \\
\hline NS4 & $0.747 *$ \\
\hline \multicolumn{2}{|l|}{$\begin{array}{c}\begin{array}{c}\text { Perceived } \\
(\mathrm{CR}=0.844)^{* *}\end{array} \\
\left(\begin{array}{l}\text { Behavioral Control } \\
\end{array}\right.\end{array}$} \\
\hline PBC1 & $0.697 *$ \\
\hline $\mathrm{PBC} 2$ & $0.629 *$ \\
\hline PBC3 & $0.542 *$ \\
\hline \multicolumn{2}{|l|}{ ZIS intent $(C R=0.870)^{* * *}$} \\
\hline NZ1 & $0.842 *$ \\
\hline NZ2 & $0.821 *$ \\
\hline NZ3 & $0.906^{*}$ \\
\hline NZ4 & $0.809^{*}$ \\
\hline
\end{tabular}

*valid (Pearson Correlation $>$ r table 0.146)

**reliable (Cronbach alpha $>0.6)$

From the results of testing the first hypothesis, the Rvalue is 0.386 , the $\mathrm{R}$ Square value is 0.149 , and the Adjusted R Square value is 0.143 . From the value of $\mathrm{R}$ Square, it can be interpreted that the variable of religious belief forms $15 \%$ of the variation in attitude. In other words, $65 \%$ of attitudes are formed by variables other than religious beliefs.

Religious beliefs have a positive and significant influence on attitudes, which can be seen from the regression test results of 0.149 , with an at-count value of 4.704 and a significance value of 0.000 . A significance value that is smaller than 0.05 means that if the religious beliefs of the Muslim community are strong, then the attitude in giving zakat, infaq, and sadaqah is getting stronger.

From testing the second hypothesis, the R-value is 0.603 , the $\mathrm{R}$ Square value is 0.364 , and the Adjusted $\mathrm{R}$ Square value is 0.359 . From the $\mathrm{R}$ Square value, it can be interpreted that the attitude variable forms $36.4 \%$ of the variation in intention to give ZIS. In other words, $63.6 \%$ 
of intentions to give ZIS were formed by variables other than attitude.

Attitude has a positive and significant effect on the intention to give zakat, infaq, and sadaqah can be seen from the results of the regression test of 0.364 , with an atcount value of 8.493 and a significance value of 0.000 . A significance value that is smaller than 0.05 means that if the attitude of the Muslim community is positive when the COVID-19 pandemic occurs, then the intention to give zakat, infaq, and sadaqah is even greater.

Furthermore, the results of testing the third hypothesis obtained an R-value of 0.613, an R Square value of 0.376, and an Adjusted R Square value of 0.371. From the value of R Square, it can be interpreted that the subjective norm variable forms $37.6 \%$ of the variation in intention to give ZIS. In other words, $62.4 \%$ of intentions to give ZIS were formed by variables other than subjective norms.

Subjective norms have a positive and significant effect on giving zakat, infaq, and sadaqah can be seen from the results of the regression test of 0.376 , with an at-count value of 8.719 significance value of 0.000 . A significance value that is smaller than 0.05 means that if the subjective norms developed in the Muslim community are positive during the COVID-19 pandemic, the intention to give zakat, infaq and sadaqah is even greater.

Tabel 4. Test Results of Direct Effect Determinant Coefficient and Adjusted R Square, t-test, and F dan test

\begin{tabular}{|c|c|c|c|c|}
\hline DeterminantCoefficient \& Adjusted R & KA $\rightarrow$ SK & $\mathbf{S K} \rightarrow \mathbf{N Z}$ & $\mathbf{N S} \rightarrow \mathbf{N Z}$ & $\mathbf{P C B} \rightarrow \mathbf{N Z}$ \\
\hline R & 0.386 & 0.603 & 0.613 & 0.369 \\
\hline R2 & 0.149 & 0.364 & 0.376 & 0.136 \\
\hline $\begin{array}{c}\text { Adjusted R Square } \\
\text { Beta Coefficient }\end{array}$ & 0.143 & 0.359 & 0.371 & 0.129 \\
\hline T & & & & \\
\hline Sig. & 4.704 & 8.493 & 8.719 & 4.450 \\
\hline Result of F test & 0.000 & 0.000 & 0.000 & 0.000 \\
\hline F & & & & 19.805 \\
\hline Sig. & 22.126 & 72.132 & 76.025 & 0.000 \\
\hline
\end{tabular}

*Significance $($ Sig. $<0.05)$

Then the results of testing the fourth hypothesis obtained an R-value of 0.369 , an R Square value of 0.136 , and an Adjusted R Square value of 0.129. From the R Square value, it can be interpreted that the perceived behavioral control variable forms $13.6 \%$ of the variation in intention to give ZIS. In other words, $86.4 \%$ of intentions to give ZIS were formed by variables other than perceived behavioral control.

Perceived behavioral control has a positive and significant influence on giving zakat, infaq, and sadaqah can be seen from the results of the regression test of 0.136 , with an at-count value of 4.450 and a significance value of 0.000 . A significance value that is smaller than 0.05 means that if the perceived behavioral control formed on each Muslim is strengthened, then the intention to give zakat, infaq, and sadaqah is greater.

The study of intention is very familiar in behavioral theories such as Theory Plan of Behavior (TPB), Theory of Reason Action (TRA), Theory of Acceptance Model (TAM). By assessing intentions within the scope implementation of zakat, infaq, and sadaqah, this research has contributed to the development of these theories.

This research contributes to the amil zakat, infaq, and sadaqah to create a ZIS management strategy during a pandemic outbreak. The study of behavioral aspects of the Muslim community proposed in this study results from empirical research in the field.

The limitation in this study is that the variables used as a measure in predicting intention are limited to religious beliefs, attitudes, subjective norms, and perceived behavioral control. This study opens the opportunity for further research to add variables that predict the intention variable. In addition, this study also provides an opportunity to elaborate on the theory of intention.

\section{Conclusion}

The attitude of Muslims in giving zakat, infaq, and sadaqah can be formed by their religious beliefs. Meanwhile, to shape Muslim intentions in giving zakat, infaq, and sadaqah, it can be built by looking at several components in attitudes, subjective norms, and perceived behavioral control. In this study, attitudes, subjective norms, and perceived behavioral control positively affect the intention to give zakat, infaq, and sadaqah during the COVID-19 pandemic. A well-managed intention will be a strong predictor in the behavior of the Muslim community in giving zakat, infaq, and sadaqah.

\section{References}

1. R. R. Forradellas, S. N. Alonso, J. J. Vázquez, M. Á. E. Fernández, and N. V. Miró, "Entrepreneurship, sport, sustainability and integration: A business model in the low-season tourism sector," Soc. Sci.,. 10, 4, 10040117, (2021).

2. M. L. Bustos et al., "Tourism in the COVID-19 context in mesotidal beaches: Carrying capacity for the 2020/2021 summer season in Pehuén Co, 
Argentina," Ocean Coast. Manag., 206, 27209 , 105584, (2021).

3. Y. XIE, “社會利用與動員遣散作為國家行動者的 律師 Social Appropriation and Demobilisation," Hongkong J. Soc. Sci., 51-88, (2020).

4. J. A. Erubami, P. Bebenimibo, and E. U. Ohaja, "Newspaper Exposure, Efficacy Feeling and Political Apathy among Youths in South-East Nigeria," Pertanika J. Soc. Sci. Humanit., 29, 3,. 1611-1629, (2021).

5. M. F. Othman and V. V. Okpe, "Assessment of Political Participation and Democratic Governance in Nigeria 's Fourth Republic," Pertanika J. Soc. Sci. Humanit., 29, 1, 547-563, (2021).

6. L. Ode, A. Safar, H. Kusuma, D. A. Harjito, and Z. Arifin, “香港社會科學學報 Political Patronage and Capital Structure of Companies in Indonesia," Hongkong J. Soc. Sci. 57, (2021).

7. C. Yee-hong, “檢視馬來西亞在中國 的戰略槓桿 機遇與挑戰 Opportunities and challenges," Hongkong J. Soc. Sci., 3-34, (2018).
8. R. K. Lai, “兩種港式粤語論述 民間中文 的語言政 治 Hong Kong-Style Cantonese The Linguistic Politics of "Chinese Textbook' by Civil Society," Hongkong J. Soc. Sci., 65-86, (2017).

9. G. Mjema, "Linear Programming Models for Estimating Weights in Analytic Hierarcy Process and For Optimization of Human Resource Allocation," Int. J. Anal. Hierarchy Process. 8,. 2, 299-317, (2015)

10. G. Liu et al., "A method to nourished beach stability assessment: The case of China," Ocean Coast. Manag., 177, 178, 166-178, (2019).

11. M. Yang and Y. Chen, “兩岸合憲性審查的展望 共 和擺設抑或 憲政門神 ? Development and Prospect of Taiwan and Chinese Mainland Furnishings of Republic or Guardian of Constitution ?," Hongkong J. Soc. Sci., 89-123, (2020).

12. S. Wang, “香港青年 教育、生涯、政治 的全球 脈絡 Youth in Hong Kong," Hongkong J. Soc. Sci., 3-25, (2017). 